\title{
The Dutch Translation and Circulation of Spinoza's Tractatus Theologico-Politicus in Manuscript and Print (1670-1694) A Computational Reconstruction
}

\author{
Lucas van der Deijl \\ University of Amsterdam, Amsterdam, the Netherlands \\ l.a.vanderdeijl@uva.nl
}

\begin{abstract}
Benedictus de Spinoza became one of the few censored authors in the liberal publishing climate of the Dutch Republic. Twenty-three years passed before the first Dutch translation of his Tractatus Theologico-Politicus (1670) appeared in print, despite two interrupted attempts to bring out a vernacular version before 1693. This article compares the three oldest Dutch translations of Spinoza's notorious treatise by combining digital sentence alignment with philological analysis. It describes the relationship between the variants, two printed versions and a manuscript, revealing a pattern of fragmentary similarity. This partial textual reuse can be explained using Harold Love's notion of 'scribal publication': readers circulated handwritten copies as a strategy to avoid the censorship of Spinozism. As a result, medium and language not only conditioned the dissemination of Spinoza's treatise in Dutch, but also affected its text in the versions published-either in manuscript or print—-between 1670 and 1694.
\end{abstract}

\section{Keywords}

Spinoza - Tractatus Theologico-Politicus - translation - scribal publication - sentence alignment - digital text analysis 


\section{Introduction $^{1}$}

In the narrative on the intellectual freedom of the Dutch Republic, Benedictus de Spinoza (1632-1677) is one of the anomalies. The seventeenth-century reception of this controversial philosopher challenges the myth about the Dutch book trade as an unconditioinal printing paradise for heterodoxy. Various scholars point at the persecution of Dutch authors and publishers of 'Spinozist' works to demonstrate that censorship in the Dutch Republic was perhaps different compared with France or England, but certainly not absent. ${ }^{2}$ Spinoza himself faced legal prohibition by the provincial High Court of Holland, Zeeland, and West-Friesland in 1674, and this politically authorized ban was not just a symbolic matter; Jonathan Israel demonstrated that the circulation of Spinoza's first major work, Tractatus Theologico-Politicus (1670), was indeed suppressed both before and after the official ban of 1674 , in spite of the generally ineffective censorship in the Dutch Republic. ${ }^{3}$ 'The notion that Spinoza's Tractatus ever circulated freely is thus a myth lacking all basis in fact', Israel argued. ${ }^{4}$ Yet five editions of the Latin original, most of them with false title-pages and fictitious imprints, made it to the book market before the end of the century, ${ }^{5}$

1 I am grateful to the valuable feedback on earlier versions of this article by Antal van den Bosch, Trude Dijkstra, Lia van Gemert, Roel Smeets, Piet Steenbakkers, Jetze Touber, Jeroen van de Ven, and the anonymous reviewers. I specifically thank Jeroen van de Ven for proofreading this article and kindly sharing many of his crucial new findings on the Dutch translations of Tractatus Theologico-Politicus, to be published in his bibliography on Spinoza's works: J.M.M. van de Ven, Printing Spinoza. A Descriptive Bibliography of the Works Published in the Seventeenth Century (forthcoming).

2 O. van Marion, 'Verboden in de Gouden Eeuw. Schrijvers, drukkers en hun strategieën', in: M. Mathijsen, Boeken onder druk. Censuur en pers-onvrijheid in Nederland sinds de boekdrukkunst (Amsterdam 2011), p. 31; I. Leemans, 'Censuur als onmacht. De omstreden Nederlandse publieke ruimte 166o-176o', in: M. Mathijsen, Boeken onder druk. Censuur en pers-onvrijheid in Nederland sinds de boekdrukkunst (Amsterdam 2011), p. 5 o.

3 J. Israel, Radical Enlightenment. Philosophy and the Making of Modernity 1650-1750 (Oxford 20o1), p. 276; J. van Eijnatten, 'Van godsdienstvrijheid naar mensenrecht. Meningsvorming over censuur en persvrijheid in de Republiek, 1597-1795', in: BMGN, 118.1 (2003), p. 2; A. Pettegree \& A. der Weduwen, The Bookshop of the World. Making and Trading Books in the Dutch Golden Age (New Haven/London 2019), pp. 11-13.

4 Israel, op. cit. (n. 3), p. 276.

5 The different prints, four in quarto and one in octavo, are classified as 'T.1' to 'T.5'. See: F. Bamberger, 'The Early Editions of Spinoza's Tractatus Theologico-Politicus', in: Studies in Bibliography and Booklore, 5 (1961), pp. 9-33; J. Kingma \& A.K. Offenberg, 'Bibliography of Spinoza's works up to 180o', in: Studia Rosenthaliana, 11.1 (1977), pp. 1-32; P. Steenbakkers, 'The text of Spinoza's Tractatus', in: Y. Melamed \& M. Rosenthal, Spinoza's 'Theological-Political Treatise.' A Critical Guide (Cambridge 2010), p. 33; R. Jagersma and T. Dijkstra, 'Uncovering 
probably due to the creative publishing strategies of Spinoza's putative publisher Jan Rieuwertsz père (c.1617-1687). ${ }^{6}$

However, those who intended to print a Dutch translation were less succesful. It would take 23 years for the first Dutch rendering of Tractatus TheologicoPoliticus to appear on the book market. However, this did not mean that Dutch translations were unavailable to readers before 1693 . The reconstruction outlined below presents traces of a circulation of manuscript translations, not just within Spinoza's circle of friends but probably also beyond. Vernacular readers of Spinoza thus turned to a different medium to make the book 'public' while avoiding censorship. This publishing strategy was common in seventeenthcentury England, as explained by Harold Love using the notion of 'scribal publication. ${ }^{7} \mathrm{He}$ described how English authors of various genres-verse, prose, music, and a range of utilitarian texts - continued to 'publish' their work in manuscript throughout the seventeenth century for various political, social, or economical reasons.

Love proposed two criteria to distinguish a 'scribal publication' from texts mediated in manuscript more generally: 'the first being whether a particular manuscript is a finished work rather than part of an as yet incomplete process of promulgation, and the second whether it remains a private rather than a public possession.8 ${ }^{8}$ The act of publication can be either 'initiatory' or 'replicatory', indicating the difference between the author allowing his or her version of the text (the 'autograph' or 'holograph') to enter the public realm as opposed to the secondary copyist who independently contributes to its further circulation in that public realm. Furthermore, scribal publication involved different agents, Love argued, and each of them used a published manuscript to different commercial or practical ends. He denoted these different publishing strategies as 'author publication', 'entrepreneurial publication' and 'user publication'. ${ }^{9}$

Spinoza's Printers by Means of Bibliographical Research', in: Quaerendo, 43 (2013), pp. 278-310.

6 Piet Visser characterised Jan Rieuwertsz 'a spider in the centre of [the] network' of Spinoza's friends and Mennonite dissidents in Amsterdam: "Blasphemous and Pernicious". The Role of Printers and Booksellers in the Spread of Dissident Religious and Philosophical Ideas in the Netherlands in the Second Half of the Seventeenth Century', in: Quaerendo, 26 (1996), p. 316. Rieuwertsz published works by the controversial Mennonite teacher Galenus Abrahamsz de Haan, Jarich Jelles, Pieter Balling, Spinoza, (probably) Lodewijk Meijer and several translations by Glazemaker.

7 First coined in his 1987 article 'Scribal Publication in Seventeenth-Century England', in: Transactions of the Cambridge Bibliographical Society 9 (1987), pp. 130-54, preceding his Scribal Publication in Seventeenth-century England (New York, NY 1993).

8 Love, art. cit. (n. 7), p. 135 .

9 Love, art. cit. (n. 7), p. 138. 
Although there are significant differences between the Dutch and English book trades and while it was arguably much easier and cheaper to print a book in Holland compared to England, the strategy of scribal publication as defined by Love also offered a useful alternative to print publication in some exceptional cases in the Dutch Republic, for instance in the publishing process of the explosive Prae-Adamitae (1655) by the French theologian Isaac la Peyrère (1596-1676). ${ }^{10}$ Since Tractatus Theologico-Politicus was similarly controversial, and given the fact that two attempts to print a translation of this book were cancelled due to effective (self-)censorship (in 1671 and 1687, see below), scribal publication may have offered vernacular readers of Spinoza's book a way to cope with the limitations of Dutch public discourse.

As a result of those limitations, the history of the first Dutch translations of Tractatus Theologico-Politicus is complicated. Three different texts comprising a full seventeenth-century Dutch translation of Tractatus Theologico-Politicus have survived: two printed editions and a manuscript. The first edition, De Rechtzinnige Theologant, of Godgeleerde Staatkundige Verhandelinge, appeared in 1693. Although published anonymously, its text certainly originated in a translation by the productive translator Jan Hendriksz Glazemaker (1619/16201682).11 The second edition appeared in 1694: Een Rechtsinnige Theologant, of Godgeleerde Staatkunde, once again printed anonymously with a fake imprint ('Hans Jurgen von der Weyl, Bremen'). The third version, in manuscript, is currently held at the collection of the National Library of the Netherlands (KB): Godgeleerde Staatkundige Verhandelinge. ${ }^{12}$ The manuscript's author, scribe, and year of production remain unknown. ${ }^{13}$ The three versions are listed below. - De Rechtzinnige Theologant, of Godgeleerde Staatkundige Verhandelinge, [trans. Jan Hendriksz. Glazemaker] ('Hamburg' [= Amsterdam]: 'Henricus Koenraad', 1693).

10 D. van Miert \& H. Nellen, 'Media en tolerantie in de Republiek der Letteren', in: $D e$ Zeventiende Eeuw, 30 (2014), pp. 3-19.

11 F. Akkerman, 'Tractatus theologico-politicus. Texte latin, traductions néerlandais et Adnotationes', in: F. Akkerman \& P. Steenbakkers, Spinoza to the Letter. Studies in Words, Texts and Books (Leiden/Boston 2005), p. 233.

12 The manuscript is bound together with a version of the Korte Verhandeling known as 'codex A': B. de Spinoza, Korte verhandeling van God, de mensch, en deszelvs welstand. Godgeleerde staatkundige verhandelinge. Nauwkeurige en nootsakelyke aenmerkingen tot beeter verstant van dit boek. National Library of the Netherlands. Ms. 75 G 15. A full digital scan of the manuscript is available on the website of the KB: https://galerij.kb.nl/ $\mathrm{kb} . \mathrm{html} \# / \mathrm{nl} / \mathrm{spinoza} /$, last accessed on 29 January 2020.

13 Fokke Akkerman dated this variant before February 1671, but his argument does not convincingly exclude other scenario's (see below).

Akkerman, art. cit. (n. 11), pp. 223-5. 
- Een Rechtsinnige Theologant, of Godgeleerde Staatkunde [etc.], [trans. unknown] ('Bremen': 'Hans Jurgen von der Weyl', 1694).

- Godgeleerde Staatkundige Verhandelinge, [trans. unknown], National Library of the Netherlands, Manuscript 75 G 15 [1670-1693].

This article offers a digital comparison of the three oldest complete Dutch translations of Tractatus Theologico-Politicus still extant. This analysis reveals an intricate process of text reuse and manuscript circulation of these translations between 1670 to 1694 , which left its traces on the surviving variants. It furthermore demonstrates the value of digital text analysis for automatically collating parallel texts and analysing their mutual relationship. After providing an overview of the translation history of Tractatus Theologico-Politicus in Dutch, this contribution proposes to understand the manuscript circulation of the translated Tractatus Theologico-Politicus during the late seventeenth century as an example of Harold Love's notion of 'scribal publication'. Viewing this history from Love's perspective illustrates the importance of circulating manuscript copies for the first Dutch reception of Spinozism, a discourse conditioned by both the language and medium used to transmit Spinoza's ideas.

\section{The Dutch Translation History of Tractatus Theologico-Politicus}

On 17 February 1671, more than a year after the publication of his Tractatus Theologico-Politicus, Spinoza wrote a letter to Jarig Jelles (1619/20-1683), which remains the oldest reference to a Dutch translation of the treatise. The philosopher reported to his Amsterdam friend:

When Professor ... visited me recently, he said, among other things, that he had heard that my Theological-Political Treatise has been translated into Dutch, and that someone (he didn't know who) intended to have it printed. So I beg you, very earnestly, to please find out about this, to prevent the printing, if that's possible. This is not only my request, but also that of many of my good friends, who would not like to see this book prohibited. If it's published in Dutch, that will doubtless happen. ${ }^{14}$

Spinoza did not fail to understand the early modern politics of translation. By February 1671, he was fully aware of the risks involved by the prospect of

14 B. de Spinoza, Ep 44, 1671.02.17, in: B.d.S., De Nagelate Schriften (s.l.s.n [Amsterdam] 1677), XLVII, p. 591; English translation cited from B. de Spinoza, The Collected Works of Spinoza, ed. E. Curley (Princeton, NJ 1985), p. 39 o. 
a vernacular translation of his Tractatus Theologico-Politicus appearing on the book market. Immediately after its publication in 1670 the treatise had been strongly condemned by ecclesiastical, civic, and academic authorities alike. ${ }^{15}$ To a certain degree Spinoza, Rieuwertsz (the book's putative publisher), and Israel de Paull (the printer of Spinoza's works) had anticipated that response - why else bother to fake the publisher's name ('Henricus Künraht', also: 'Künrath') and location of publication ('Hamburg')? ${ }^{16}$ They all knew the limits of the tolerance permitted to Dutch authors. These had been outlined by the Placcaet against Socinian gatherings and literature issued by the States of Holland in 1653, the prohibition of Cartesian academic teaching by the States of Holland and West-Friesland from 1656, and the case of Spinoza's friend Adriaan Koerbagh (1633-1669), who died in a prison cell in 1669 shortly after he got locked up for publishing his Een bloemhof van allerley lieflijkheyd sonder verdriet (1668). ${ }^{17}$

Nevertheless, the philosopher apparently considered the publication of a Latin edition harmless if his name would be omitted. Both Rieuwertsz and Spinoza had managed to escape any suppression thus far, and official statements seldom led to actual prosecution. But when a Leiden bookshop selling Tractatus Theologico-Politicus was raided in May 1670, Spinoza must have latched on to the fact that a formal ban was not required for censorship to take effect. ${ }^{18} \mathrm{He}$ seems to have been overwhelmed by the aggressive response from different sides. ${ }^{19}$ Particularly painful was the rejection by those Spinoza regarded his allies: the Cartesians. ${ }^{20} \mathrm{~A}$ number of those symphatising with the Cartesian philosophy —already suspect among the orthodox Calvinists-felt compelled to take a stance, ranging from Johannes Bredenburg (1641-1691), a controversial collegiant in Rotterdam, to Regnerus van Mansveld (1639-1671), professor of philosophy at the University of Utrecht. ${ }^{21}$ To make matters worse,

15 Israel, op. cit. (n. 3), pp. 275-6.

16 For a reconstruction of the identification of De Paull as the printer of Spinoza's Tractatus Theologico-Politicus see Jagersma and Dijkstra, art. cit. (n. 5).

17 Th. Verbeek, Descartes and the Dutch. Early Reactions to Cartesian Philosophy 16371650 (Carbondale/ Edwardsville 1992); W. van Bunge, From Stevin to Spinoza. An Essay on Philosophy in the Seventeenth-Century Dutch Republic (Leiden/Boston 2001), p. 73; Vreederijk Waarmond [= Adriaan Koerbagh], Een bloemhof van allerley lieflykheyd sonder verdriet, geplant door Vreederijk Waarmond, tot nut en dienst van al die geen die der nut en dienst uyt trekken wil. Of Een vertaaling en uytlegging van al de Hebreusche, Grieksche, Lat., Franse en andere vreemde bastaart-woorden en wijsen van spreeken, (Amsterdam 1668).

18 Israel, op. cit. (n. 3), p. 276.

19 Cf. B. de Spinoza, Ep. 68, September/October 1675.

$20 \quad$ S. Nadler, Spinoza. A Life (Cambridge 1999), p. 234; Spinoza, Ep. 68.

21 Key publications on Bredenburg are: L. van Bunge, Johannes Bredenburg (1643-1691). Een Rotterdamse collegiant in de ban van Spinoza (PhD thesis Rotterdam 1990); A. Fix, 
the provincial High Court of Holland, Zeeland, and West-Friesland did at last legally formalise the censorship that was de facto already in place. Four years after the publication of the first edition, on 19 July 1674, the Hof van Holland issued the 'Placaet tegens de Sociniaensche Boecken Leviathan en andere' prohibiting the publication and distribution of Tractatus Theologico-Politicus (among other works). ${ }^{22}$ By then, however, Spinoza already realised he had crossed a line. The philosopher did whatever was needed to minimise the risk to his personal safety by trying to prevent a vernacular edition of his treatise from being printed. ${ }^{23}$

In Spinoza scholarship it is assumed that the translation implied by the nameless 'Professor' in the letter to Jelles concerns Glazemaker's version included in the first printed Dutch translation: De Rechtzinnige Theologant. This letter suggests that neither the book's publisher (probably Rieuwertsz), Jelles, nor Glazemaker had asked their good friend permission for the translation. ${ }^{24}$ An odd situation, yet it is unlikely that the letter refers to a different translation, which indeed never appeared in 1671 . After all, Spinoza's friends significantly edited the letters and texts compiled in Spinoza's posthumous Opera Posthuma (1677) and its Dutch equivalent De Nagelate Schriften (1677). ${ }^{25}$ Most likely they also anonymised letter XLVII (Spinoza's letter to Jelles from 17 February 1671 , included in the Opera Posthuma) to protect those involved in the publication process, including Glazemaker, Rieuwertsz, and Jelles. I therefore follow the accepted view that Spinoza's letter to Jelles refers to Glazemaker's translation. More specifically, that letter refers to an early version of the Dutch translation eventually printed in 1693 entitled De Rechtzinnige Theologant.

A second important source for understanding the translation history of Tractatus Theologico-Politicus is the KB manuscript of Godgeleerde Staatkundige Verhandelinge. Akkerman established that this manuscript contains

Prophecy and Reason. The Dutch Collegiants in the Early Enlightenment (Princeton, NJ 1991), pp. 215-46; Israel, op. cit. (n. 3), pp. 342-58. An analysis of Van Mansveld's disposition and refutation of Tractatus Theologico-Politicus can be found in J. Touber, Spinoza and Biblical Philology in the Dutch Republic, 1660-1710 (Oxford 2018), pp. 93-102.

22 The other books were Thomas Hobbes's Leviathan; [Lodewijk Meyer's] Philosophia Sacrae Scripturae interpres; and Frans Kuyper's (among others) Bibliotheca Fratrum Polonorum. Cf. Israel, op. cit. (n. 3), p. 275 .

23 Spinoza, Ep 44.

24 Nadler deduced that Rieuwertsz simply had not told Spinoza (Nadler, op. cit. (n. 20), p. 297), whereas Israel acknowledged that it 'seems strange that Spinoza should have been unaware of Rieuwertsz' and Glazemaker's plans to bring out a Dutch version' (Israel, op. cit. (n. 3), p. 278).

25 P. Steenbakkers, Spinoza's Ethica from Manuscript to Print. Studies on Text, Form and Related Topics (Assen 1994), p. 6 (e.g.); Steenbakkers, art. cit. (n. 5), pp. 36-7. 
a corrected copy of Glazemaker's (lost) holograph. ${ }^{26}$ Glazemaker translated directly from Spinoza's original manuscript, Akkerman argued. ${ }^{27}$ As the corrections did not make it to the eventual 1693 print, Akkerman assumed that the printer used Glazemaker's holograph of the translation (or an identical copy of it) in $1693{ }^{28}$ The manuscript contains a second clue for a reconstruction of the chronology: a substantial part of the pages (ending on page 379) is marked with line numbers and marginal signatures outlining the page composition for a type setter. Akkerman therefore suggested that Godgeleerde Staatkundige Verhandelinge served as a corrected and tidied printer's copy in 1671. Akkerman's reconstruction thus holds that someone was about to print a corrected copy of Glazemaker's text as early as February 1671 . Then, after Spinoza withdrew the project, the printer's copy survived as the KB manuscript. However, while Akkerman's account sufficiently shows that this copy has once been used in a print shop at an early stage in the printing process; it is not sufficient to date the manuscript before 1671 . Hypothetically speaking this manuscript could also comprise the model Ten Hoorn used for his attempt to print a translation in 1687, which was also frustrated red-handed and therefore could likewise explain the sudden end of the sheet calculations on page 379 (see below).

In any case, it seems likely that Glazemaker's now lost holograph was not used for further dissemination. It ended up in a drawer, possibly until the translator's death in 1682. Instead, Jelles and his friends must have copied the edited version of Glazemaker's translation (preserved in the KB manuscript Godgeleerde Staatkundige Verhandelinge) to create additional copies. We can reconstruct this stage in the treatise's reception history from the work by Jeroen van de Ven, who recently discovered and described a fourth, fragmentary Dutch version of Tractatus Theologico-Politicus included in De waerheyt van de christelijcke godts-dienst, a chapter-by-chapter refutation of Tractatus Theologico-Politicus, by the Dordrecht grain broker Willem van Blijenbergh. ${ }^{29}$ In his attack on Spinoza's treatise, finished in 1672 and published in 1674, Van

26 Thus dismissing the 'volkommenste Übereinstimmung' Gebhardt perceived between the KB manuscript and the 1693 print. Akkerman, art. cit. (n. 11), p. 227; C. Gebhardt, 'Die alten holländischen Übersetzungen des Tractatus Theologico-politicus', vol. 4, in: Chronicon Spinozanum (The Hague 1926), p. 275.

27 Akkerman, art. cit. (n. 11), p. 225.

28 Akkerman speculates that Spinoza's friend Johannes Bouwmeester should be regarded the most likely candidate for this editor, but there is no compelling evidence for identification (Akkerman, art. cit. (n. 11), p. 233).

29 J.M.M. van de Ven, “Van bittere galle by een gebonden". Over de laat zeventiende-eeuwse Nederlandse vertalingen van Spinoza's Tractatus Theologico-Politicus', Mededelingen van de Vereniging van het Spinozahuis (Rijnsburg 2019); Van de Ven, op. cit. (n. 1). 
Blijenbergh abundantly cited Tractatus Theologico-Politicus in a Dutch translation derivated from Glazemaker's. ${ }^{30}$ Van Blijenbergh is unlikely to have produced this translation himself because of his poor proficiency in Latin, but more importantly because of the clear similarity to Glazemaker's version of the text. ${ }^{31}$ More specifically, Van de Ven qualified Van Blijenbergh's citations closest to the version included in the KB manuscript Godgeleerde Staatkundige Verhandelinge. Apparently, Van Blijenbergh had access to a copy of this version as early as September 1672 , from which he selected the (slightly edited) citations. ${ }^{32}$ It is unlikely that Van Blijenbergh acquired this copy from Spinoza himself in 1672 since he was no longer Spinoza's friend or correspondent by then: the philosopher had ended his contacts with Van Blijenbergh in 1665, annoyed by the latter's impatience and maelstrom of endless questions. ${ }^{33}$ Van Blijenbergh's refutation thus suggests that Spinoza did not necessarily control the distribution of copies: the copying of Glazemaker's translation happened on a 'replicatory' basis and reached beyond the immediate 'inner circle' of Spinoza's friends. ${ }^{34}$ Possibly, copies of the translation already started to circulate between 1671 and 1672 .

The protagonist Physiologus from the anonymous spinozist novel Vervolg van 't leven van Philopater (1697, attributed to Johannes Duijkerius), might reveal the next episode in this history. In a dialogue with his like-minded friends he explains that one 'Doctor in de Medicynen en illuster Philosooph'-likely to be identified as Lodewijk Meyer (1629/3o-81) — possessed the holograph of Glazemaker's translation at a certain moment and enriched it with marginal glosses containing key terminology in Latin. ${ }^{35}$ Physiologus also informs the

30 W. van Blijenbergh, De waerheyt van de christelijcke godts-dienst en de authoriteyt der H. Schriften, beweert tegen de argumenten der ongodtsdienstige, of een wederlegginge van dat godt-lasterlijcke boeck, genoemt Tractatus theologico-politicus (Leiden 1674).

31 Van Blijenbergh requested Spinoza in his letter to the philosopher dated 16 January 1665 , to answer him in the vernacular. W. van Blijenbergh, 'Willem van Blijenbergh aan de weledele heer B.d.S', (Ep. 2o), in: B. de Spinoza, Briefwisseling, eds. F. Akkerman, H. Hubbeling \& A.G. Westerink (Amsterdam 1977), pp. 183-4.

32 The author mentioned the completion in a letter to the Utrecht theologian Frans Burman (1628-79) from 2 September 1672. Van de Ven, art. cit. (n. 29).

33 B. de Spinoza, Ep. 27, 1665.06.03; Cf. Van de Ven, art. cit. (n. 29).

34 Several studies have contributed to our understanding of Spinoza's social milieu, most noteably: K.O. Meinsma, Spinoza en zijn kring. Over Hollandse Vrijgeesten (Utrecht 1980 [1896]); W. Klever, Mannen rond Spinoza. Presentatie van een emanciperende generatie 1650-1700 (Hilversum 1997); Nadler, op. cit. (n. 2o); Israel, op. cit. (n. 3); H. Krop, Spinoza. Een paradoxale icoon van Nederland (Amsterdam 2014); M. Rovere, Le clan Spinoza. Amsterdam 1677, l'invention de la liberté (Paris 2017).

35 J. Duijkerius, Het leven van Philopater, Vervolg van 't leven van Philopater, ed. Gerardine Maréchal (Amsterdam 1991), p. 195. 
gentlemen assembled in Philopater's home that several handwritten copies of the original translation had been circulating during the two long decades prior to the first printed edition. Many of those copies were corrupted, he adds, but a faithful version of the original was kept by a 'singulier goed vriend' (a singular good friend: probably Meyer). That version eventually found its way to the press in 1693. Most likely, the version implied here is the one included in De Rechtzinnige Theologant. Furthermore, according to Physiologus, one of the corrupted copies was also printed, which probably refers to the 1694 edition, Een Rechtsinnige Theologant. ${ }^{36}$ This key passage reads as follows:

Moreover I could tell you Gentlemen about this that so many copies during that sequence of years, after a copy of the original without doubt was given to a singular good friend who in turn had given it to someone else, were born, that due to manifold and crooked transcription it would have evoked little respect for the Translator to confront the last ones with the first in case it was published under his name, or at least in case one would believe that one of these latest copies had also been translated by Glazemaker. ${ }^{37}$

It remains uncertain who published Glazemaker's translation or kept the holograph during the eleven years between Glazemaker's death and the publication of De Rechtzinnige Theologant. All potential candidates from the 'old' circle of Spinoza-Bouwmeester, Jelles, Rieuwertsz père, Meyer—had been long dead in 1693. The most likely option is that Rieuwertsz's son inherited the document in 1687 and finally finished the job his father left undone. This would be in line with the account of Stolle and Hallmann, who reported that Rieuwertsz fils possessed a translation of Tractatus Theologico-Politicus in manuscript and refused to reveal the name of its author. ${ }^{38}$

Another document possibly referring to a different Dutch translation of Tractatus Theologico-Politicus can be found in the archives of the Reformed

$36 \quad$ Duijkerius, op. cit. (n. 35), p. 196.

37 The original quote reads: 'Wijders weet ik 'er u Heeren nog dit van te zeggen dat 'er zoo veel afschriften in die reeks van jaaren, na dat 'er een afschrift van 't origineel buiten twijffel aan een singulier goed vriend en die weer aan een ander was gegeven, geboren wierden dat de laatsten by 't eerste te confronteren door veelvoudig en kreupel uitschrijven tot weinig respect van den Vertaaler zou geweest zijn, indien het op zijn naam, of ten minste indien men geloofde dat zodanig een laatste afschrift ook van Glazemaker dus vertaalt was, was uitgekome'. Duijkerius, op. cit. (n. 35), p. 195.

38 J. Freudenthal, Die Lebensgeschichte Spinozas in Quellenschriften, Urkunden und nichtamtlichen Nachrichten, mit der Unterstützung der Königl. Preussischen Akademie der Wissenschaften (Leipzig 1899), pp. 227-8; Akkerman, art. cit. (n. 11), p. 235. 
Church in Amsterdam. ${ }^{39}$ A record of the church council assembly on 9 January 1687 reports that Jan Claesz ten Hoorn, a publisher of Cartesian treatises and medical books, was in the process of printing a translation from a manuscript someone had sent him from Delft. ${ }^{40}$ When delegates from the consistory confronted Ten Hoorn with the rumour, the accused at first denied any involvement. But he confessed after they showed him letters from Delft implicating the publisher. When summoned before the consistory Ten Hoorn testified he had burned all material, both the pages already in print and the manuscript used for typesetting. ${ }^{41}$ However, should we take the liberty to assume Ten Hoorn committed another 'godtloos leugen' (godless lie) and secretly preserved the manuscript, then a scenario becomes plausible in which the allegedly burnt text comprised Glazemaker's translation. Perhaps it was Ten Hoorn who published De Rechtzinnige Theologant: he kept the manuscript and finally managed to publish the text six years later. After all, Glazemaker was not a stranger to Ten Hoorn. They collaborated intensively during the years before Glazemaker's death in 1682: Ten Hoorn issued several (re-)prints from Glazemaker's translated oeuvre during the 168os-including the collected works of the French philosopher René Descartes (1596-1650), and two voluminous prose novels, D'Argenis van J. Barklai (1680) and Vervolg op D'Argenis van J. Barklai (1681). One is tempted to believe that Glazemaker not only permitted Ten Hoorn to reprint his Descartes-translations but also entrusted him with the publication of De Rechtzinnige Theologant. This scenario would confirm Physiologus's remark about the postponed printing of Glazemaker's translation due to interventions - the plural implies more than one-from the 'ecclesiastijke' (ecclesiastic) authorities. ${ }^{42}$ However, the repeatedly mentioned origin of the manuscript by the consistory report as Delft, complicates this scenario. The case might as well involve one of the 'corrupted' copies of Glazemaker's translation, or a different translation altogether.

Finally, after a twenty-three-year period in which nobody managed to bring out a full printed translation, two Dutch editions appeared briefly after another. At first glance the similarity between both prints is striking. The 1694 edition adopted the (ironically ambiguous) title of its predecessor from 1693, which evidently was not part of the original title: 'De Rechtzinnige Theologant' versus 'Een Rechtsinnige Theologant' ('the / a right-minded theologian',

39 Cf. G.F.L. Peeters, 'Jan Claesz ten Hoorn and Spinoza's Tractaet', in: Quaerendo, 13 (1983), pp. 239-41.

40 I. Leemans, Het woord is aan de onderkant. Radicale ideeën in Nederlandse pornografische romans 1670-1700 (Nijmegen 2002), p. 280.

41 Peeters, art. cit. (n. 39), p. 240.

42 Duijkerius, op. cit. (n. 35), p. 195. 
'reasonable theologian' or 'orthodox theologian'). The unknown publisher of the 1694 edition probably copied the title for commercial reasons. In a preface included in Een Rechtsinnige Theologant, the printer ridicules the 'grote omslag en boehay' ('extravagancy and affectation') to add the marginal glosses in De Rechtzinnige Theologant enriching the text with the original Latin terminology. Since the printer used a manuscript without marginalia, he felt the need to argue why those glosses were useless anyway. ${ }^{43}$ Perhaps the sudden publication of De Rechtzinnige Theologant came as a surprise to the publisher of Een Rechtsinnige Theologant when he was still preparing the print. The edition was less carefully produced than De Rechtzinnige Theologant: it is full of misprints and omits, for instance, the passages in Hebrew from Spinoza's quotes from the Torah. Possibly he sped up the process fearing to miss the boat. To ensure the return on his investment, he tried to profit from the sales of De Rechtzinnige Theologant by camouflaging his edition as a reprint, with almost the same title, publication dates (1694 instead of 1693), and fake imprint (Bremen instead of Hamburg) on its title page. ${ }^{44}$

From this confusing history we can draw a few reasonably certain conclusions: historical sources contain proof of two attempts (in 1671 and 1687) to print a full Dutch translation of Tractatus Theologico-Politicus before 1693. Both initiatives were cancelled prematurely, once by Spinoza himself and at least once by the Reformed Church in Amsterdam. Furthermore, judging from the dialogue of the fictional character Physiologus, the travel report from Stolle and Hallmann, the fragmentary translation included in Van Blijenbergh's De waerheyt van de christelijcke godts-dienst, and Akkerman's reconstruction, it seems fairly certain that different copies of at least one translation (most likely Glazemaker's), but possibly more circulated in manuscript between the early 1670s and early 169os. This use of the scribal medium is in line with the fact that other texts by Spinoza widely circulated in manuscript among the philosopher's friends before appearing in print, as mentioned by Jelles in his 'Voorreden' appended to the Nagelate Schriften. ${ }^{45}$ Physiologus also stressed

43 Anonymous ['Hans Jürgen van der Weil'], 'De Drukker Aen den Leeser: Wegens de Marginalen en Kantteykeningen', in: Anonymous [= B. de Spinoza], Een Rechtsinnige Theologant, of Godgeleerde Staatkunde (Bremen [= Amsterdam] 1694), p. * $2^{-{ }^{*}} 3 \mathrm{v}$.

44 Another scenario is that the publisher of De Rechtzinnige Theologant was informed of the upcoming translation of Tractatus Theologico-Politicus and immediately started to print his edition to outmanoeuver his competing colleague for his competing colleague. The version published in De Rechtzinnige Theologant was, after all, probably ready for print right away.

45 Steenbakkers, op. cit. (n. 25), p. 38; Anonymous, [Jelles], 'Voorreeden', op. cit. (n. 14), p. ${ }^{* * * * *} 2 \mathrm{v}$. 
that because of the large number of disseminated copies, a widening gap emerged between different text versions. ${ }^{46}$ Thus he sketched an image of a vernacular reception of Tractatus Theologico-Politicus that due to censorship remained independent from print for over two decades, consisting of readers who relied upon copies of copies of a translation of Spinoza's Latin manuscript. This scenario of an early reception of handwritten copies provides a crucial background to understand the relationship between the three surviving first Dutch translations of Tractatus Theologico-Politicus.

\section{Previous Work}

A number of studies touched upon the relationship between the three surviving versions. As already stated above, Akkerman qualified the KB manuscript Godgeleerde Staatkundige Verhandelinge as a mere revision of Glazemaker's holograph that would eventually be published as De Rechtzinnige Theologant in 1694. The two printed editions have often been confused as a result of the superficial similarity in their title and colophon. In Johannes Colerus's early biography of Spinoza, for instance, the author seems to refer to the 1693 edition because he identifies Glazemaker as its translator. However, he also mentions that the book was published in 1694 and complains that the translator had slandered ('bekladden') Bremen as its city of origin, the fake imprint mentioned on the title-page of the 1694 edition Een Rechtsinnige Theologant. ${ }^{47}$ Moreover, Thijssen-Schoute acknowledged the existence of remarkable similarities in the body of both texts, thus suggesting the resemblance was not limited to the title. ${ }^{48}$

However, there are valid objections to the supposed similarity between the versions. Gebhardt claimed that De Rechtzinnige Theologant and Een Rechtsinnige Theologant were modelled after different editions of the original Latin. He qualified the two editions 'völlig unabhängig von einander' 49 Based on bibliographical analysis of misprints, Van de Ven supported Gebhardt's claim regarding the different sources of the two editions, proving that

\footnotetext{
46 Duijkerius, op. cit. (n. 35), p. 195.

47 J. Colerus, De waarachtige verryzenis Jesu Christi uit den dooden, tegen B. de Spinosa en zyn Aanhangers verdeedigt (Amsterdam 1705), pp. 166-7.

48 L. Thijssen-Schoute, 'Jan Hendrik Glazemaker. De zeventiende eeuwse aartsvertaler', in: L. Thijssen-Schoute, Uit de republiek der letteren. Elf studiën op het gebied der ideeëngeschiedenis van de Gouden Eeuw (The Hague 1967), p. 261; Cf. Kingma \& Offenberg, art. cit. (n. 5), p. 23 .

49 Gebhardt, art. cit. (n. 26), p. 275.
} 
Glazemaker translated either from the first Latin edition (T.1, 1670) or directly from Spinoza's holograph (or an apograph of it), whereas the translatorcomposer of Een Rechtsinnige Theologant (also) used two later editions as his exemplar (T.4n/T.4, 1677 or later; T.5, 1677 or later)..$^{50}$ Akkerman also agreed with Gebhardt: 'En réalité la nouvelle version [Een Rechtsinnige Theologant] était totalement indépendante par rapport à l'autre [De Rechtzinnige Theologant] — comme Gebhardt l'a déjà constaté. ${ }^{11} \mathrm{He}$ recognised a distinct style and language in Een Rechtsinnige Theologant, which he classified as less clear and transparent to a modern reader than Glazemaker's. And indeed, a cursory examination confirms the difference between the versions. Een Rechtsinnige Theologant is evidently not a reprint and contains a version far from identical to the version published as De Rechtzinnige Theologant.

After closer inspection, however, the claims by Gebhardt and Akkerman on the mutual independance of De Rechtzinnige Theologant and Een Rechtsinnige Theologant do not hold for the entire text. Jongeneelen's analysis provided evidence of textual reuse of De Rechtzinnige Theologant in chapter 3 and in other parts of Een Rechtsinnige Theologant too. ${ }^{52}$ How could these scholars reach such contradictory conclusions based on the same material? Akkerman's comparison of the printed translations remains superficial (he focused on Godgeleerde Staatkundige Verhandelinge) and Gebhardt's claims are only based on his assessment that the two editions were taken from different prints of the Latin source, which he proves by referring to one misprint in the first Latin edition tacitly copied in De Rechtzinnige Theologant but not in Een Rechtsinnige Theologant. ${ }^{53}$ Thijssen-Schoute's analysis in turn is limited to her correct but unsupported observation about the high degree of similarity between the print versions.

The paradoxical truth is that each variant contains evidence to prove both the similarity and the distance between the other two versions. The claims made so far were grounded in close inspection of selected samples. Sampling is a valid and often necessary method for comparing larger documents or datasets, especially since a systematic comparison between long texts like translations of Tractatus Theologico-Politicus remains a difficult endeavour.

$5^{\circ} \quad$ Van de Ven, op. cit. (n. 1).

$5^{1}$ 'In fact, the new version was entirely independent compared to the other one-like Gebhardt already established'. Akkerman, art. cit. (n. 11), p. 235. Akkerman also articulated his impression that even though the 1694 edition clearly copied elements from the title-page of the 1693 edition, it seems none from Spinoza's circle had been involved in its publication (art. cit. (n. 11), p. 236). vvdghj.cuccfree.org/kv/KV/ch21.html\#idp133396992, last accessed 1 May 2019. 
However, sampling only works if one can guarantee the representativeness of the sample. This article seeks to demonstrate that the samples selected for analysis in previous studies were not representative for the overall relationship between the three variants. Thus, the disagreement between Gebhardt, Akkerman, Thijssen-Schoute, and Jongeneelen was the result of a methodological problem.

It is my aim to overcome this problem through a full digital comparison using transcripts of the three variants. Computational analysis renders sampling unnecessary because it enables the collation task to be automated. Digital transcripts can be analysed line by line with an algorithm computing the similarity (or lexical 'sameness') per sentence pair. The advantage of this method is not just its efficiency: a full digital comparison also enables us to quantify and visualize lexical difference, to easily extract patterns in different translating styles, and to replicate the analysis using the same text pairs (or others). However, manual collation of mono-lingual textual variants is as old as the discipline of philology itself, and the benefit of philological methodology remains, of course, uncontested. Moreover, any application of digital text analysis to historical material needs to be validated through manual analysis of samples. Therefore, I combined automatic collation with manual scrutiny, as a two-way approach to the historical problem at hand. The sections below report the methodological setup and results of this two-way comparison between De Rechtzinnige Theologant, Een Rechtsinnige Theologant and Godgeleerde Staatkundige Verhandelinge.

\section{A Note on Method: Automatic Collation}

First, a note on method is now in order. To compare a pair of equivalent translations on sentence level, three consecutive tasks are to be automated:

1. the collation (alignment) of parallel sentences from two parallel translations;

2. the evaluation of similarity (or distance) between the sentences aligned in task (1);

3. the extraction of different words per aligned sentence pair.

This section only explains the metrics used for step 2 , the evaluation of similarity. Understanding these metrics is necessary to interpret the results reported below. Appendix A explains the methodology in more detail. A technical description can be found in the code and documentation available on GitHub. ${ }^{54}$

54 The code can be reviewed and replicated with an annotated Jupyter Notebook available on GitHub: https://github.com/lucasvanderdeijl/automatic_collation. 
The similarity between aligned sentences is formalised using three different textual features: words, combinations of words ('n-grams'), and charactersexpressed as cosine similarity, BLEU, and Levensthein distance respectively (see appendix A for more details). Each metric represents similarity as a normalised score between $\mathrm{o}$ and 1.o, where $\mathrm{o}$ indicates zero overlapping words, n-grams or characters. A score of 1.0 will be assigned to a pair of identical sentences. As a result of their focus on different analytical units, each metric results in different values ranging between $o$ and 1.o. This variance is 'a feature, not a bug': the different metrics are deliberately combined as a means for comparison and as cross-validation. It is the correlation between the metrics which is meaningful in this context rather than the specific values associated with them. Finally, note that the calculation of character similarity using Levenshtein distance allows us to evaluate the possible influence of spelling variation in our analysis: a pair of parallel sentences where each equivalent contains exactly the same words but in a different spelling will still result in a significantly higher score than a pair of sentences with additional differences on the lexical level.

\section{Computational Analysis}

Figure 1 displays the similarity between all successfully aligned sentences from De Rechtzinnige Theologant and Een Rechtsinnige Theologant (represented by the BLEU metric). The horizontal axis represents the numbers of each aligned sentence pair (from beginning to end), and the Y-axis displays the BLEU score of the two corresponding equivalent sentences. First, the graph confirms that overall, both editions mediate different text versions. We can deduce this from the low mean similarity (BLEU-score) between the aligned sentences (Mean $(\mathrm{M})=0.16$; Number of aligned sentences $(\mathrm{N})=1672$; Standard Deviation $(\mathrm{SD})=$ o.19). This average can be classified as 'low' given the fact that parallel (human) translations-including the cases under scrutiny here-are very unlikely to score the maximum value of 1.o. Papieneni et al. reported an average score of 0.35 with four reference translations in a test corpus of 5 oo parallel sentences. ${ }^{55}$ Values far below this score (between o and o.2) can be considered to indicate low similarity and a high degree of independence from one another. When the average B LEU-score in a comparison of two parallel texts drops below o.1, one

55 K. Papineni, et al., 'BLEU: a Method for Automatic Evaluation of Machine Translation', in: Proceedings of the 4oth Annual Meeting of the Association for Computational Linguistics $(A C L)$ (Philadelphia 2002), pp. 315-16. 


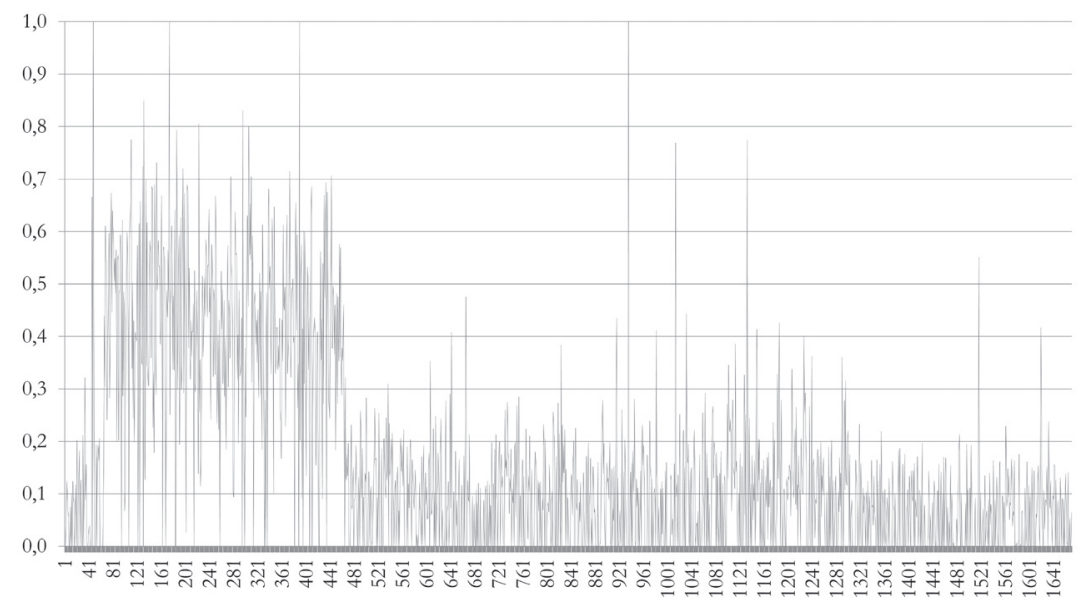

FIGURE 1 BLEU-score per aligned pair of equivalent sentences from De Rechtzinnige Theologant and Een Rechtsinnige Theologant

can safely assume that the two translations were created independently. The same applies to fragments or chapters: a similarity below o.1 on the BLEU-scale between a pair of parallel chapters provides a strong indication that these equivalent chapters are independent and have been translated by different translators.

However, a large section in the first parts of the text shows a pattern clearly deviating from the average level of similarity. The change between both parts of the graph can be located quite accurately (see Figure 2). When broken down by individual chapters, this analysis reveals an essential difference between chapters 1 to 4 on the one hand and the preface and chapters 5 to 20 on the other hand. The mean similarity rises after the preface and drops directly after the fourth chapter. Assuming that Glazemaker's translation (in any case finished in 1671, printed in 1693 in De Rechtzinnige Theologant) was older than the variant in Een Rechtsinnige Theologant, we can conclude from this graph that his translation also functioned as a model for the first four chapters of Een Rechtsinnige Theologant, with a high mean BLEU score ranging between 0.39 and 0.44 . In contrast, the preface and chapters 5 to 20 were translated independently from Glazemaker's translation, with an average BLEU-score ranging between 0.09 and 0.13 . The same pattern can be observed when using Cosine similarity or normalised Levenshtein similarity. In other words, one can prove the unrelatedness of the two variants by studying the preface or the chapters after the fourth, which support the 'independence'-thesis articulated by Gebhardt and Akkerman. The first four chapters, however, provide evidence for the thesis of similarity and textual reuse suggested by Thijssen-Schoute and Jongeneelen. 


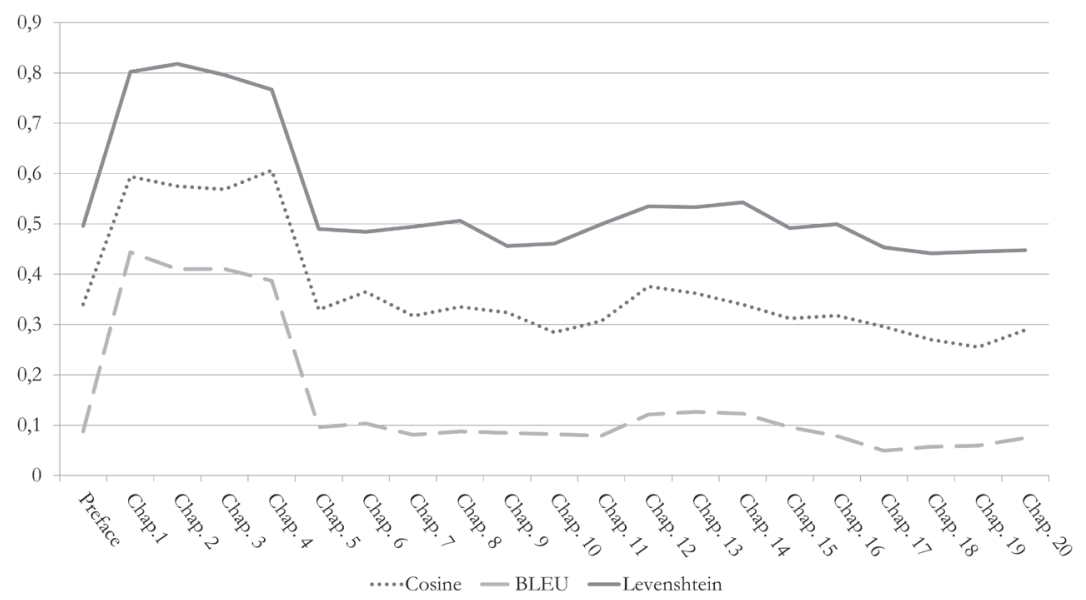

FIGURE 2 Mean similarity by chapter between aligned pairs of equivalent sentences from De Rechtzinnige Theologant and Een Rechtsinnige Theologant

While clearly revealing different genealogies, Figure 2 indicates that substantial parts of Een Rechtsinnige Theologant and De Rechtzinnige Theologant originated in the same model nonetheless: Glazemaker's manuscript.

The overall similarity between De Rechtzinnige Theologant and Godgeleerde Staatkundige Verhandelinge $(\mathrm{M}=0.28 ; \mathrm{N}=1697 ; \mathrm{SD}=0.18)$ is considerably higher than the overlap between the two print versions, which is - arguablyin line with Akkerman's claim that 'la traduction du manuscript est essentiellement celle de Glazemaker'.56 Again, however, that claim does not hold for all chapters. Figure 3 shows that Godgeleerde Staatkundige Verhandelinge contains an independent translation of chapter 5 and 9 (with a remarkably low average BLEU-score of 0.06 and 0.06 ). Note that the overall similarity in most 'similar' chapters in Figure 3 is lower compared to Figure 2 due to the relatively high degree of spelling variation in the manuscript.

Finally, the relation between Een Rechtsinnige Theologant and Godgeleerde Staatkundige Verhandelinge again deviates from the two patterns observed so far (see Figure 4). It resembles the relation between De Rechtzinnige Theologant and Een Rechtsinnige Theologant - which is in line with the high similarity between De Rechtzinnige Theologant and Godgeleerde Staatkundige Verhandelinge - with the exception of chapter 5 . The two equivalent versions of chapter 5 from Een Rechtsinnige Theologant and Godgeleerde Staatkundige Verhandelinge overlap to a high degree. Yet, the equivalent versions of

$5^{6}$ 'the translation of the manuscript essentially is Glazemaker's'. Akkerman, art. cit. (n. 11), p. 227. 


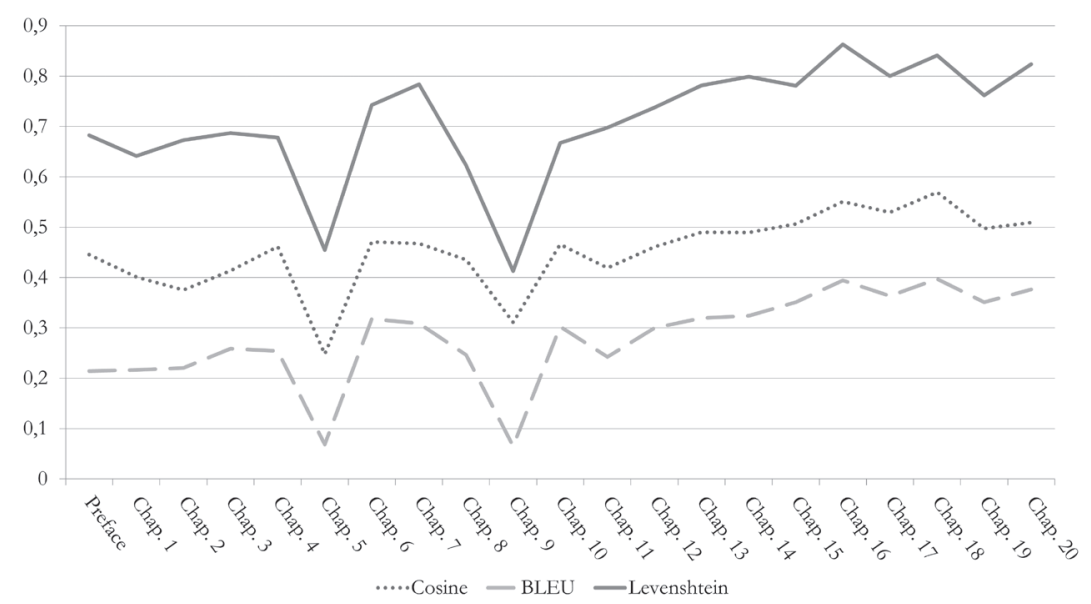

FIGURE 3 Mean similarity by chapter between aligned pairs of equivalent sentences from De Rechtzinnige Theologant and Godgeleerde Staatkundige Verhandelinge

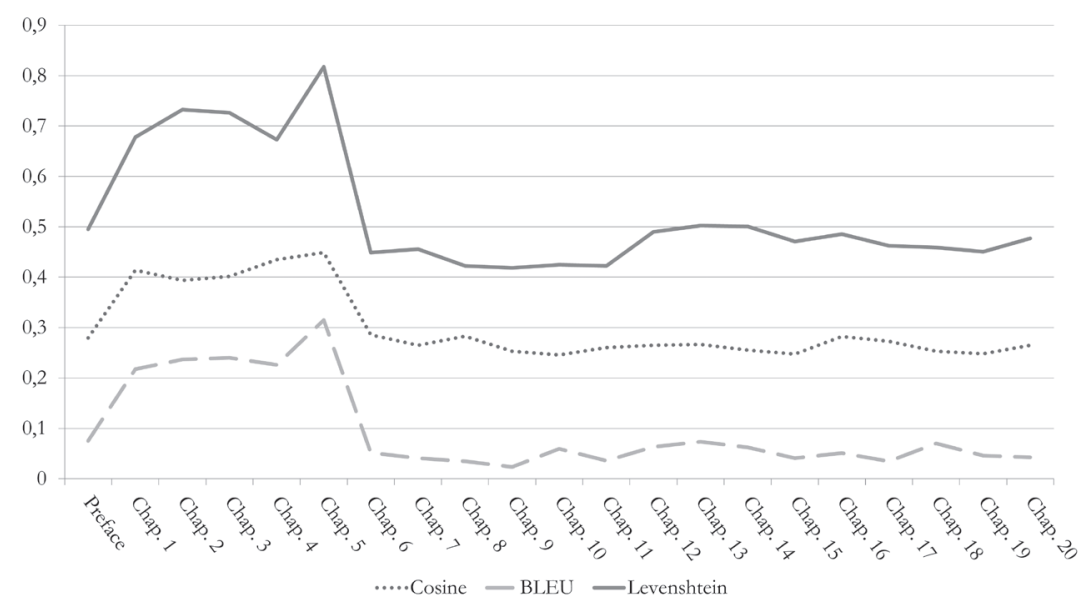

FIGURE 4 Mean similarity by chapter between aligned pairs of equivalent sentences from Een Rechtsinnige Theologant and Godgeleerde Staatkundige Verhandelinge

chapter 5 from Een Rechtsinnige Theologant and De Rechtzinnige Theologant are unrelated. Note that this overlap between Een Rechtsinnige Theologant and Godgeleerde Staatkundige Verhandelinge was not observed in chapter 9: each version comprises an independent variant of that chapter.

The computational analysis indicates that each version contains substantial fragments overlapping with the equivalent parts from the other two 


\begin{tabular}{|llllllllllllllllllllll|}
\hline & P. & 1 & 2 & 3 & 4 & 5 & 6 & 7 & 8 & 9 & 10 & 11 & 12 & 13 & 14 & 15 & 16 & 17 & 18 & 19 & 20 \\
\hline DRT & A & A & A & A & A & A & A & A & A & A & A & A & A & A & A & A & A & A & A & A & A \\
\hline ERT & B & A & A & A & A & B & B & B & B & B & B & B & B & B & B & B & B & B & B & B & B \\
\hline GSV & A" & A" & A" & A" & A" & B & A" & A" & A" & A" & C & A" & A" & A" & A" & A" & A" & A" & A" & A" & A" \\
\hline
\end{tabular}

FIGURE 5 Text versions A, B and C and their derivates in De Rechtzinnige Theologant (DRT), Een Rechtsinnige Theologant (ERT) and Godgeleerde Staatkundige Verhandelinge $(G s v)$ by chapter.

variants. Chapters 1, 2, 3, and 4 overlap in all versions although in different degrees, meaning that these chapters originate in the same root translation. Overall, Godgeleerde Staatkundige Verhandelinge is more similar to De Rechtzinnige Theologant than to Een Rechtsinnige Theologant in all chapters except for chapter 5, where Godgeleerde Staatkundige Verhandelinge is closer to Een Rechtsinnige Theologant. Each version contains a different (independent) version of chapter 9 (cf. Figure 5). Computational analysis of Tractatus Theologico-Politicus thus reveals a remarkable process of intertextual, partial reuse of copies that originated in Glazemaker's lost manuscript (version A, published in De Rechtzinnige Theologant), which occurred simultaneously to the production and circulation of at least two translations (B and C) and possibly more variants created independently from Glazemaker's translation.

\section{Philological Comparison}

Philological analysis of chapter 5 and chapter 9 confirms the pattern observed in the computational approach. The variation in Table 1 (Appendix B) contains a sentence pair from Een Rechtsinnige Theologant and Godgeleerde Staatkundige Verhandelinge with an exceptionally high BLEU-score (0.59). It clearly exemplifies the rare resemblance between Een Rechtsinnige Theologant and Godgeleerde Staatkundige Verhandelinge, and their unrelatedness to De Rechtzinnige Theologant in this chapter. Furthermore, the sentence variation quoted in Table 2 (Appendix B) illustrates the mutual independence of each version in chapter 9 . The differences between the variants cannot be explained as transcription errors or different spelling preferences. The syntax is significantly different in all versions, which suggests that chapter 9 has been translated by three different, independent translators between 1670 and 1694.

One needs to keep in mind, however, that the graphs display a highly summarised image of the relationship between the versions per chapter. A closer 
look in the texts and a glance at the many peaks in Figure 1 reveals that variation occurs even within the supposedly similar chapters: all versions of the first four chapters are far from identical. The parts from Een Rechtsinnige Theologant and Godgeleerde Staatkundige Verhandelinge originating in (copies of) Glazemaker's manuscript underwent profound revision and manipulation. Appendix B lists two examples showing both a 'very similar' and a 'very dissimilar' set of variants from chapter 1 to show this intra-chapter variation.

The first example is cited in Table 3 (Appendix B). The equivalent sentences clearly confirm that each version of the chapter indeed originated from a common root. Apart from minor orthographic differences ('nooit' vs. 'noit', 'naar' vs. 'na', 'zou' vs. 'sou') and one grammatical difference ('hem' vs. 'hen')—which is a mistake or misprint in De Rechtzinnige Theologant ('ipsi' in the original Latin is dative masculine singular of 'ipse') - the sentences are identical. A similar overlap can be found in Godgeleerde Staatkundige Verhandelinge which features different but similarly small orthographic deviations ('ofte' vs. 'of'; 'besluyten' vs. 'besluiten'). These deviations are probably caused by different spelling preferences among copyists and/or typesetters. Moreover, the quote from Genesis was not borrowed from any of the existing Dutch Bible translations. That indicates it was introduced in the root translation (it comprises a literal translation of the verse as quoted in Latin by Spinoza). ${ }^{57}$ In short, sentence pairs like these confirm that none of the three Dutch renderings of Tractatus Theologico-Politicus are entirely unrelated to the other two variants.

A comparison with a 'very dissimilar' sentence pair from chapter 1 (Table 4, Appendix B) indicates that while parts of the three versions stem from the same root, other parts seem to belong to three different branches of that root. The cited example proves Akkerman's claim that the manuscript is essentially a corrected version of Glazemaker's rendering. In this case the corrections were indeed improvements of minor grammatical errors or inadequacies. Glazemaker, for instance failed to translate the superlative in 'miserrimum' ('zoo ellendigen' vs. 'elendige') and his translation of 'ad hujus exemplar' as 'op deze wijze' (vs. 'volgens dit voorbeeld') was slightly inadequate. Remarkably, while the composer/translator of Een Rechtsinnige Theologant also corrected

57 The passage from Genesis 6:3 was translated differently in the Lutheran translation (1648), the States translation (1637), the Deux-Aes Bijbel (1562), and the Leuvense Bijbel (1548): 'De menschen willen hen mijnen Geest niet meer straffen laten; want sy zijn vleesch' (Lutheran translation); 'Mijn Geest zal niet in eeuwigheid twisten met den mens, dewijl hij ook vlees is' (States translation); 'De menschen willen hen [door] mynen gheest niet meer straffen laten / want sy zijn vleesch' (Deux-Aes Bijbel); 'Mijnen gheest en sal eewelijt inden mensch niet blijven / want hy vleesch es' (Leuvense Bijbel). 
these errors in his version of the equivalent sentence, he preferred alternative phrases ('alderellendigsten' vs. 'zoo ellendigen', 'tot sulk een voorbeeld' vs. 'volgens dit voorbeeld'). This seems to suggest that whereas parts of Een Rechtsinnige Theologant and Godgeleerde Staatkundige Verhandelinge share the same root, there is no mutual dependence between them: they contain manipulations from two different translators or editors who both corrected Glazemaker's errors in their own way.

\section{Conclusion: the Dutch Tractatus Theologico-Politicus as 'Scribal Publication'}

In contrast with earlier studies, this article demonstrates that neither $D e$ Rechtzinnige Theologant, Een Rechtsinnige Theologant, nor Godgeleerde Staatkundige Verhandelinge is entirely unrelated to the other two versions. The fragmentary textual reuse in each version proves that several chapters share a common root, whereas other chapters are translated independently. Computational analysis enabled an accurate description of the fragmentary similarity between De Rechtzinnige Theologant and Een Rechtsinnige Theologant. The preface and chapters 5 to 20 from both versions are mutually independent whereas the equivalent chapters 1 to 4 originated in a shared genealogy. The relationship between these two printed editions, on the one hand, and the surviving manuscript on the other, is equally complex. Except for chapter 5 and 9 (significantly different in all versions), Godgeleerde Staatkundige Verhandelinge contains merely a revised version of an early variant of the text published in De Rechtzinnige Theologant. Een Rechtsinnige Theologant is independent from Godgeleerde Staatkundige Verhandelinge in all chapters but chapter 5 .

While revealing different textual genealogies, this study acknowledges Glazemaker's key role in the Dutch translation history of Tractatus TheologicoPoliticus and agrees with Akkerman's assessment of the De Rechtzinnige Theologant as a (relatively) direct, unmodified printed reproduction of Glazemaker's lost manuscript. His manuscript served as the model of the first four chapters in all three studied variants. Akkerman's claim that Godgeleerde Staatkundige Verhandelinge predates De Rechtzinnige Theologant also remains uncontested. Besides Glazemaker, the sources revealed the hand of at least two different editors or translators: one responsible for the edits in Glazemaker's version in Godgeleerde Staatkundige Verhandelinge and another for both the correction of the first four chapters of Glazemaker's version published in Een 
Rechtsinnige Theologant and the new translation of the other chapters in Een Rechtsinnige Theologant. ${ }^{58}$

The changes made by these editors and translators in the variants are traces of an intricate copying process. Their edits did not necessarily introduce corruptions of the Latin source. Instead, some notable adjustments to Glazemaker's version (as published in De Rechtzinnige Theologant) present in Een Rechtsinnige Theologant and Godgeleerde Staatkundige Verhandelinge were deliberate improvements of the typical kind of translation errors thatlike Akkerman argued — have become like a fingerprint of Glazemaker, whose incredibly large production came at the cost of a lifetime of relentless haste. ${ }^{59}$ Both Een Rechtsinnige Theologant and Godgeleerde Staatkundige Verhandelinge were composed by translators and editors who engaged not only with existing translation(s) at their disposal but also with a version of the Latin source. Between 1670 and 1694, Glazemaker was only one among at least three translators who faitfully rendered Spinoza's Tractatus Theologico-Politicus in Dutch. Their joint effort to reduce the distortion in the Dutch representations of Spinoza's language remains a testament to their respect for his philosophy.

This patchwork overlap between the three versions of the Dutch Tractatus Theologico-Politicus requires an explanation. For this, one should, I argue, turn to the dissemination of the treatise in manuscript. The complex history of the production and the merging of different variants suggests the protagonist Physiologus from Vervolg van 't leven van Philopater was probably right once again: various copies of at least one Dutch translation circulated in manuscript during the two decades after 1670 . Besides its distribution in full copies, readers probably disseminated the treatise fragmentarily in separate chapters, which is also illustrated by the fact that in 1683 a separate English translation appeared of Spinoza's chapter 6 'Miracles No Violations of the Laws of Nature', attributed to Charles Blount, years before the first full English edition of the treatise came to light in $1689 .{ }^{60}$ Most likely, several now lost intermediary

$5^{8}$ Although it is possible that different editors or translators should be held responsible for the parts that were merely corrected and the parts that were translated anew in Een Rechtsinnige Theologant.

59 Akkerman, art. cit. (n. 11), pp. 227. For an overview of Glazemaker's oeuvre see Catalogus bij een tentoonstelling over de vertaler Jan Hendriksz Glazemaker in de Universiteitsbibliotheek van Amsterdam, ed. M. Keyser (Amsterdam 1982).

6o Steenbakkers, art. cit. (n. 5), p. 37. The first English reception of Tractatus TheologicoPoliticus was conditioned by "anxiety about a revival of 'ancient Atheists" and controversies about miracles became a key topic in this then current and pressing debate, which explains the decision to only publish this particular chapter. Van de Ven, op. cit. (n. 1). 
copies preceded at least two of the three versions extant today (Een Rechtsinnige Theologant and Godgeleerde Staatkundige Verhandelinge). Once the publisher of Een Rechtsinnige Theologant eventually dared to bring the text to the press in 1694, the only text(s) at his (or her) disposal was a version that had been copied and edited several times during the previous two decades. He or she probably needed to merge different chapters from different handwritten copies, each with its own genealogy of intensive transcription, copying and revision.

The dissemination of Dutch translations of Spinoza's Tractatus TheologicoPoliticus before the first printed edition could thus be explaind as an exceptional Dutch case of the phenomenon of 'scribal publication'. Harold Love was the first to acknowledge that handwritten copies remained a major instrument for sharing texts throughout the seventeenth century, two centuries after the invention of printing. The manuscript copies traced in this article comply to Love's definition of the phenomenon: these texts comprise full copies of a treatise finished by the author (or translator) by the time of 'publication', and they are made available for reading outside of the author's immediate private sphere but within a particular, restricted group of likeminded readers. Once released within this group, Spinoza no longer retained control over the distribution of copies, which were recopied for personal use ('user publication') on a 'replicatory' basis.

Love stressed this social function of the scribal publication: handwritten documents became instrumental to 'bonding groups of likeminded individuals into a community, sect or political faction, with the exchange of texts in manuscript serving to nourish a shared set of values and to enrich personal allegiances' ${ }^{61}$ As a result, the distinction between manuscript and print media also created a separation of discourses: using Love's notion of 'scribal publication' Henk Nellen and Dirk van Miert demonstrated that different social codes of intellectual exchange applied to the handwritten and the printed domain in the seventeenth-century Dutch public sphere. ${ }^{62}$ Reconstructing the reception of the Prae-Adamitae (1655), they observed that many years before its publication La Peyrère's book had been circulating fragmentarily in letters and yet did not evoke the aggressive response following the first printed publication in 1655. In a similar vein, Spinoza's like-minded peers recognised the potential of the scribal publication to translate, disseminate, and read his theologicalpolitical critique in Dutch between 1670 and 1693. The strategy of scribal publication was certainly not as widespread in the Dutch book trade as it was in

$61 \quad$ Love, op. cit. (n. 7), p. 177.

$62 \quad$ Van Miert \& Nellen, art. cit. (n. 10). 
the English, but the manuscript medium specifically proved to be useful with publications that required extra caution.

In other words, the Dutch reception of Spinoza's notorious treatise illustrates the double standard concerning tolerance in the Republic's multilingual reading culture, both regarding language and medium. To a certain degree tolerance depended on the author's willingness to stay within the safe boundaries of Latin discourse. Steven Nadler was probably right when he claimed that Spinoza's friend Adriaan Koerbagh might have escaped a tragic death, locked up and neglected in the Amsterdam Rasphuis in 1669, had he not been so foolish to publish his radical religious criticism in Dutch. ${ }^{63}$ Between the 1670 os and 169os, Spinozist books in Latin were most unwelcome in the Dutch Republic, but vernacular spinozism was outright unacceptable-Spinoza himself understood this very well. And yet, while the authorities were successful in their attempt to prevent a print version of the Dutch translation up until 1693, they could not stop its dissemination in manuscript. The remarkable Dutch translation and circulation of Tractatus Theologico-Politicus marks the limits of censorship in the Dutch Republic, and foregrounds the creativity of Spinoza's readership to satisfy their curiosity for this 'book forged in hell'.64

\section{Appendix A. Methodology}

In the computational analysis conducted for this study, three different tasks have been automated:

1. the collation (alignment) of parallel sentences from two parallel translations;

2. the evaluation of similarity (or distance) between the sentences aligned in task (1);

3. the extraction of different words per aligned sentence pair.

Computational linguists developed various algorithms and evaluation metrics for the first two steps. They designed methods for sentence alignment in both monolingual and multilingual corpora, which require different approaches with different purposes. ${ }^{65}$ For instance, algorithms for aligning parallel text in monolingual corpora aim to recognise similar paragraphs and sentences from unrelated texts about

\footnotetext{
63 Nadler, op. cit. (n. 20), p. 297.

64 Cf. S. Nadler, A Book Forged in Hell. Spinoza's Scandalous Treatise and the Birth of the Secular Age (Princeton, NJ 2011), pp. xi-xv.

65 R. Nelken and S. Shieber, "Towards Robust Context-Sensitive Sentence Alignment for Monolingual Corpora', in: nth Conference of the European Chapter of the Association for Computational Linguistics (2006), p. 161. For a clear example of the application of sentence alignment in historical research, see: D. Edelstein, R. Morrissey, and G. Roe, 'To
} 
related topics (e.g. news articles from different news agencies covering the same (kind of) event). ${ }^{66}$ The task at hand here (aligning sentences from a pair of parallel Dutch translations of the same source text) can profit from results obtained through this approach, especially since the comparison between these parallel translations is expectedly less complicated than the intended application mentioned above. After all, the lexical similarity between parallel sentences from the texts at stake here is much larger than in loosely-related news articles. Therefore, this study adopts procedures for sentence alignment in monolingual corpora developed within the field of computational linguistics.

More specifically, our application borrowed two basic principles from literature about sentence alignment: (1) dividing the procedure in 'macro alignments' (alignment of equivalent paragraphs or windows of sentences) and 'micro alignment' (alignment of equivalent sentence-pairs from the aligned window-pairs);67 (2) ranking candidate paragraphs and sentences according to cosine similarity based on so-called $t f$-idf values of all words from the paragraph or sentence (using paragraphs as 'documents' on the macro level and sentences on the micro level). ${ }^{68}$ To account for splits or merges of equivalent sentences, the algorithm allows alignment with multiple sentences, which is necessary because none of the studied editions follows the punctuation of the source text consistently. Moreover, spelling has not been normalised because orthographic differences are also significant for the question at stake here. Finally, a threshold was introduced to reduce the number of mismatches: only if the cosine similarity between the reference sentence and the candidate sentence with the highest cosine similarity was higher than o.1, an aligned sentence pair was established. Once two parallel sentences were successfully aligned, all lexical or orthographic differences between both sentences could be extracted easily for further (manual) analysis by saving all words from the reference sentence not occurring in the candidate sentence and vice versa.

Quote or Not to Quote. Citation Strategies in the Encyclopédie', in: Journal of the History of Ideas, 74 (2013), pp. 213-36.

66 Cf. R. Barzilay and N. Elhadad, 'Sentence Alignment for Monolingual Comparable Corpora', in: EMNLP 'о3 Proceedings of the 2003 Conference on Empirical Methods in Natural LanguagePprocessing (Stroudsburg, PA 2003), p. 25.

67 Barzilay \& Elhadad used basic word overlap to compute cosine similarity. Barzilay \& Elhadad, art. cit. (n. 66), p. 26. Nelken and Shieber proposed to refine this method by taking the $t f-i d f$ values of each word, thus giving more importance to less frequent words. They also propose to consider paragraphs and sentences as documents. Nelken and Shieber, art. cit. (n. 65), p. 163. The use of $t f-i d f$ also improved the performance of sentence alignment in multilingual corpora, as demonstrated by X. Ma, 'Champollion. A Robust Parallel Text Sentence Aligner', in: Proceedings of the Fifth International Conference on Language Resources and Evaluation (LREC 'o6) (2006), pp. 489-92.

Barzilay and Elhadad, art. cit. (n. 66), p. 28. 
To compute the similarity between sentence pairs aligned in step 1 , this analysis applied three different metrics, each representing a different level of complexity: cosine similarity of $t f$-idf values, BLEU score, and normalised Levenshtein distance (converted to a similarity metric by subtracting the score from 1.0). Cosine similarity is a standard measure for lexical similarity between sentences or documents and represents the angle between two vectors of equal length, where each vector contains a series of $t f-i d f$ values per sentence for all distinct words from the reference and the target sentence. ${ }^{69}$ A pair of two identical texts would thus be represented as two identical vectors with an angle between them of $o^{\circ}$ and a cosine of 1.o. Any differences between aligned sentences result in a larger angle, with a maximum of $90^{\circ}$, equaling a cosine of o. Note that this measurement does not take into account word order nor differences between insertions, deletions, and substitutions of characters: it is a 'bag of words'-approach.

A more advanced comparison can be made using the BLEU-score, which is a standard in the field of machine translation. ${ }^{70}$ It was designed with the purpose of automating quality evaluations of machine-produced translations. ${ }^{71}$ That quality is assessed by comparing a candidate translation produced by a machine with a reference text of one or multiple human translations. The BLEU-score is a 'numerical 'translation closeness' metric', which is based on the number (represented in a score between o and 1) of matching unigrams (words) and n-grams from the reference and the candidate translation. ${ }^{72} \mathrm{~A}$ BLEU-score of 1 represents an identical match; a score of o indicates no matching words (and by extension n-grams) at all. The metric is computed by counting the matching 1-, 2-, 3- and 4-grams, regardless of position in the sentence, and by assigning an equal weight to each of these four scores $(25 \%)$. This standard is often referred to as 'BLEU-4'. Thus BLEU takes word order into the equation (two matching bigrams result in a higher score than four matching non-adjacent unigrams) and can therefore be regarded a more accurate metric than cosine similarity.

Finally, similarity between the three versions is calculated using the Levenshtein distance between all sentences from the aligned sentence pairs. ${ }^{73}$ This metric, also known as 'edit distance', was developed by the Russian mathematician Vladimir Levenshtein to indicate the minimal number of insertions, substitutions and deletions needed to transform a given string $\mathrm{X}$ to another string $\mathrm{Y} .{ }^{74}$ The absolute Levenshtein

69 Cosine similarity was computed using the spatial-module from the SciPy package for Python.

70 Bleu-score was computed using the sentence_bleu module from the NLTK package for Python.

71 Papineni, et al., art. cit. (n. 55), p. 311.

72 Papineni et al., art. cit. (n. 55), p. 311.

73 Levenshtein distance was computed using the Distance package for Python.

74 First published in V. Levenshtein, 'Binary codes capable of correcting deletions, insertions, and reversals', in: Soviet Physics Doklady, 10.8 (1966), pp. 707-10. 
distance indicates the sum of all character transformations needed in the shortest path between $\mathrm{X}$ and Y. For instance: the Levenshtein distance between 'cat' and 'rat' equals 1 (substitution); the distance between 'cat' and 'rats' equals 2 (1 substitution and 1 insertion). To compare the distance between sentences from different aligned sentence pairs, the Levenshtein metric was normalised by dividing the sum of all edits with the string length of the shortest of both strings. ${ }^{75}$ For the sake of consistency with the other metrics, Levenshtein distance was then converted into a similarity measure by subtracting it from 1.o. This again resulted in a number between o (indicating two strings without a single matching character at the same position) and 1.0 (indicating two identical strings).

\section{Appendix B. Philological Comparison}

TABLE 1 A very similar sentence pair $(\mathrm{BLEU}=0.59)$ from chapter 5 of Een Rechtsinnige Theologant and Godgeleerde Staatkundige Verhandelinge ${ }^{\text {a }}$

\section{Version Sentence (page)}

TTP (1670) sed ad nostrum propositum revertamur, \& alia Scripturæ loca, quæ pro cæremoniis nihil præter corporis commoda, \& pro solâ lege divina universali beatitudinem promittunt, in medium proferamus. (57)

DRT (1693) Maar laat ons weêrkeren tot 't voorgaande, en andere plaatzen der Schriftuur aanhalen, die tot beloning der kerkplichten niets als ligchamelijke voordélen beloven, daar in tegendeel voor d'algeméne Goddelijke wet alleen de gelukzaligheit op word toegezeid. (86)

ERT (1694) Maar laat ons weer tot ons voorstel komen, en andere plaatsen der Schrift voort brengen, die voor de Ceremonien, niets dan nuttigheden des lichaams, en voor de algemene Goddelijke Wet alleen, de saligheid, beloven. (71)

GSV (?) Maar laat ons weer tot ons voorstel komen, en andere plaatzen der Schrift, voort brengen, die voor de Ceremonien niets dan nuttigheeden des lighaams, en voor d'algemeene goddelyke wet, alleen de Zaligheid belooft. (189v-19or)

a All Latin citations are taken from the first quarto edition of Tractatus Theologico-Politicus: Bamberger T.1 (1669/1670).

75 Following the normalisation implemented in the Distance package for Python ('method 1'). 
TABLE 2 A very dissimilar sentence pair $(\mathrm{BLEU}=0.06 / 0.07)$ from chapter 9

\section{Version Sentence (page)}

TTP (1670) Horum præcipuum est, quod Hezras (eum pro Scriptore prædictorum librorum habebo, donec aliquis alium certiorem ostendat) narrationibus in hisce libris contentis ultimam manum non imposuit, nec aliud fecit, quam historias ex diversis scriptoribus colligere (115)

$D R T$ (1693) Het voornaamste hier van is, dat Esdra (die ik zo lang voor de schrijver der voorgenoemde boeken zal houden, tot ymant my een ander en zekerder toont) de laatste hand aan de verhalingen in deze boeken begrepen, niet gelegt heeft, maar niet anders gedaan, als de geschiedeniszen uit verscheide schrijvers vergadert [etc.] (175)

ERT (1694) 't Voornaamste deser is, dat Hesdras (deselve sal ik voor de Schrijver der voorseide Boeken houden, tot dat ymand een beter aanwijse) aan de verhalingen welke in dese Boeken begrepen zijn, sijn laatste werk niet gelegt heeft, en niet anders heeft gedaan, als Historien uit verscheidene Schrijvers te versamelen [etc.] (143)

GSV (?) 'T voornaamste hieraf is, dat Hezras (ik zal hem voor de Schryver der voorgedachte boeken houden, tot dat iemand die zekerder is toond) de verhaalingen in deze boeken begreepen, niet voltooyt heeft, en niets anders gedaan dan de historien uyt verscheyde schryvers te vergaderen [etc.] (272v)

TABLE 3 A relatively similar sentence pair (BLEU score: o.73) from a relatively similar chapter pair (chapter 1)

\section{Version Sentence (page)}

TTP (1670) Sic etiam intelligendus est Genes. cap. 6. vers. 3. בא ידון רוחי באדם לעולם non ratiocinabitur (aut non decernet) Spiritus meus in homine unquam, quoniam caro eset, hoc est, homo posthac ex decretis carnis \& non mentis, quam ipsi, ut de bono discerneret, dedi, aget. (11)

DRT (1693) Dus moet ook de plaats, die in het boek der Scheppinge Cap. 6: v. 3. staat, verstaan worden, לא ידון רוחי באדם לעולם בגשם הוא בשר mijn geest zal nooit in de mensch redeneren (of besluiten) om dat hyvleesch is, dat is; de mensch zal voortaan naar de besluiten van 't vleesch [p.17] werken, niet naar die van de geest, dewelke ik aan hen gegeven heb, op dat hy onderscheid in 't goede maken zou. (16-17) 
TABLE 3 A relatively similar sentence pair (BLEU score: o.73) (cont.)

\section{Version Sentence (page)}

ERT (1694) Dus moet ook de plaats, die in 't boek der scheppinge (Cap. 6: 3.) staat, verstaan worden: Mijn Geest sal noit in de mensch redeneren (of besluiten) om dat hyvleesch is: dat is, de mensch sal voortaan na de besluiten van 't vleesch werken, en niet naar die van de geest, dewelke ik aan hem gegeven heb, op dat hy onderscheid in 't goede maken sou. (13) Dus moet ook deze plaats, die in 't boek der Scheppinge, Cap. 6.v.3. staat, verstaan worden; Myn geest zal nooyt in den mensch redeneren (ofte besluyten) om dat hy vleesch is; dat is de mensch zal voort aan naar de besluyten van 't vleesch werken, niet naar die van des geest, dewelke ik aan hen gegeven heb, op dat hy den onderscheyd in 't goede maaken zoude. (126r, '14')

TABLE 4 A relatively dissimilar sentence pair (BLEU score: 0.11 ) from a relatively similar chapter pair (chapter 1)

\section{Version Sentence (page)}

TTP (1670) Quibus præsentem populi miserrimum statum intellexit, ejusdem vero futuræ calamitates, verbis, tanquam à Deo prolatis, ei revelatæ fuerunt. Et ad hujus exemplar multa possem adferre exempla ex sacris literis, nisi putarem ea omnibus esse satis nota. (6)

$D R T$ (1693) Door welke beelden hy de tegenwoordige elendige staat van 't volk verstaan heeft ; maar haar toekomende elenden zijn hem door woorden, als van God komende geöpenbaart, en op deze wijs zou ik veel voorbeelden uit de Schrift konnen bybrengen, ten zy ik dacht, dat dezelve yder een genoegzaam bekent waren. (9)

ERT (1694) Door welke dingen, hy den tegenwoordigen alderellendigsten staat des volks heeft verstaan: Maar de toekomende ellenden zijn hen door woorden, als van God voort gebracht, geopenbaart geworden. En tot sulk een voorbeeld, sou ik uit de heilige schrift, veel voorbeelden konnen by een brengen, indien ik niet meende, dat die dingen, aan alle genoegsaam bekend waren. (7) 
TABLE 4 A relatively dissimilar sentence pair (BLEU score: o.11) (cont.)

Version Sentence (page)

GSV

Door welke zaaken hy den teegenwoordigen ende zoo ellendigen staat des volks heeft verstaan, ende zyn des zelfs plaagen die zy te verwachten hadden, door woorden als van god gesprooken aan hen geoopenbaard. Ende volgens dit voorbeeld zoude ik nog veele uyt de Heylige Schrift konnen by brengen, ten zy ik vermoede, dat die by alle [illegible] genoeg bekend zijn. (121r, ' 8 ') 